\title{
A pilot survey on perceptions and knowledge of generic medicines among consumers in Penang, Malaysia
}

\author{
Nabil A. AL-GEDADI, Mohamed A. HASSALI, Asrul A. SHAFIE.
} Received (first version): $10-$ Oct-2007

Accepted: 6-Feb-2008

\begin{abstract}
${ }^{*}$
Objective: To explore the consumers' perceptions and knowledge towards issues surrounding generic medicines utilization in Penang, Malaysia.

Methods: A cross sectional survey was conducted with consumers who attended the annual University open day. Using convenience sampling, survey forms were distributed to the respective consumers via the help of a group of trained 1st year pharmacy students. For a period of 5 days, 400 respondents had participated in the survey. Analysis of the response from the collected forms yielded in 396 usable forms.

Results: Only $28.3 \%(\mathrm{n}=112)$ of the respondents were familiar with the term "generic medicines". More than $70 \%$ of the respondents do not know that generic medicines can be marketed under different names. About 34\% ( $n=38)$ of consumers stated that they had been given information regarding generics by their pharmacists. In terms of side effects, about $32 \%(n=127)$ of the respondents felt that generic medicines may cause more side effects than branded medicines. Majority of the consumers surveyed (64\%) understand that generic cost less compared to their branded counterparts.

Conclusion: This survey showed that there is a gap in consumers' knowledge and understanding about generic medicines. The findings also suggest that direct patient education by the healthcare providers on issues relating to safety and efficacy of generic medicines could further enhance their uptake.
\end{abstract}

Keywords: Drugs, Generic. Health Knowledge, Attitudes, Practice. Malaysia.

\section{ESTUDIO PILOTO SOBRE PERCEPCIONES Y CONOCIMIENTO DE MEDICAMENTOS GENÉRICOS ENTRE CONSUMIDORES EN PENANG, MALASIA}

\section{RESUMEN}

Objetivo: Explorar las percepciones y conocimientos de los consumidores hacia asuntos relacionados con la utilización de medicamentos genéricos en Penang, Malasia.

Métodos: Se realizó un estudio transversal con consumidores que asistieron al día de puertas abiertas anual de la Universidad. Utilizando una muestra de conveniencia, se distribuyeron cuestionarios a los consumidores auxiliados por estudiantes entrenados de primer curso de farmacia. Durante un periodo de 5 días, participaron en el estudio 400 respondentes. El análisis de las respuestas rindió 396 cuestionarios utilizables. Resultados: Sólo el 28,3\% (n=112) de los respondentes estaban familiarizados con el término "medicamento genérico". Mas del 70\% no sabía que los medicamentos genéricos podían comprarse bajo diferentes nombres. Alrededor del 34\% ( $\mathrm{n}=38)$ de los consumidores afirmó que había recibido información sobre los genéricos de su farmacéutico. En términos de efectos adversos, cerca del $32 \%(n=127)$ de los respondentes sentía que los medicamentos genéricos podían causar más efectos adversos que los de marca. La mayoría de los consumidores encuestados $(64 \%)$ entendía que los genéricos contaban menos en comparación con sus equivalentes de marca.

Conclusión: Este estudio demostró que hay un vacio entre el conocimiento y la comprensión de los consumidores sobre los medicamentos genéricos. Los hechos también demuestran que la educación directa al paciente pro parte de los profesionales sanitarios sobre asuntos relativos a seguridad y eficacia de los genéricos podría elevar su uso.

Palabras clave: Medicamentos genéricos. Practica, actitudes, conocimiento sobre salud. Malasia.

\section{INTRODUCTION}

A generic medicine is a multisource pharmaceutical product which is intended to be interchangeable with the comparator product. It is usually manufactured without a license from the innovator company and marketed after the expiry of patent or
Pharm).PhD candidate, Discipline of Social and Administrative Pharmacy, School of Pharmaceutical Sciences,Universiti Sains Malaysia. Penang, (Malaysia). Mohamed A. HASSALI. BPharm(Hons), MPharm(Clin Pharm), PhD. Lecturer, Discipline of Social and Sciences, Universiti Sains Malaysia. Penang, (Malaysia) Asrul Akmal SHAFIE. B.Pharm(Hons), Pg Dip(Health Econ), PhD. Lecturer, Discipline of Social and Administrative Pharmacy, School of Pharmaceutical Sciences, Universiti Sains Malaysia. Penang, (Malaysia). 
other exclusivity rights. ${ }^{1}$ In recent years, the use of generic medicines has been steadily increasing internationally, as a result of economic pressure on medicines budgets. ${ }^{2,3}$ In Malaysia the saving that can be achieved by consumers if they opt for generics had been quoted around $60 \%{ }^{4}$ In many countries throughout the world, the practice of generic prescribing and substitution is strongly supported by health authorities, and Malaysia is no exception.

In Malaysia before the medicines can be made available to the market, they are required to be registered by the Drug Control Authority (DCA) which is one of the executive bodies under the Ministry of Health (MOH). All manufacturers, importers and wholesalers are required to register with the DCA and need to renew their licenses annually. ${ }^{5}$ There are essentially three stages in the process for registration of a pharmaceutical product in Malaysia. The first stage is to evaluate if the active ingredient is registrable with the DCA. The second stage entails the evaluation of the quality of the pharmaceutical product by performing quality control tests at the National Pharmaceutical Control Bureau (NPCB). The third stage consists of an evaluation of the application for registration by looking into the quality, efficacy and safety of the product, based on the documents and data submitted. In most cases, approval takes between eighteen to thirty-six months after the application forms had been submitted. ${ }^{6}$

To be licensed, manufacturers must be in full compliance with the code of Good Manufacturing Practice (GMP) based on the World Health Organization Code. Manufactures are also subjected to regular and surprise inspection by the DCA inspectors. Malaysia is also a member of the World Trade Organization (WTO) since 1995 and acceded to the Trade-Related Aspects of Intellectual Property Rights (TRIPS) agreement in $1998 .^{7}$ In accordance with TRIPS, the Malaysian Patents Act 1983 was amended in 2000 to extend the duration of patents to twenty years from the date of filing from the previous term of fifteen years. ${ }^{8}$ In early 1998, as a result of currency crisis, the government called for the usage of locally made generics as prices of imported drugs (both generics and branded) rose sharply. ${ }^{9}$

For most consumers it is a better choice to buy a generic medicine that is cheaper and given that it can produce the same therapeutic effect. Unfortunately various factors tend to result in a greater use of branded expensive drugs than is therapeutically justified, in particular the widespread belief among the public that the branded product is better or safer than the generic. ${ }^{10}$ Although there are a few studies published elsewhere on the perceptions held by consumers to generics ${ }^{11-13}$, in the developing country such as Malaysia there were no prior studies undertaken to elicit the views of consumers pertaining to the use of generic medicines. Furthermore their knowledge on the issues surrounding generic medicines remained unexplored. Therefore the main objective of this study is to explore Malaysian consumers' perceptions and opinions of generic medicines and to identify barriers to their use of generic medicines.

\section{METHODS}

A draft questionnaire was developed after extensive literature review on the studies focusing on consumer knowledge and perceptions towards generic medicines using electronic databases which are available from the university library databases. Four main databases were used for this purpose (MEDLINE, Springer Link, Science Direct and International Pharmaceutical Abstracts (IPA)). Face and content validations of the initially developed questionnaire were done by five pharmacy academics and 10 consumers.

The final questionnaire consists of three parts. The first part of the questionnaire was on respondent's demographic profiles. The second part consists of questions exploring their knowledge to generics and the final part consists of statements pertaining to their current perceptions towards generic. Using convenience sampling methods, consumers who attended the annual university open day were chosen as potential participants. Survey forms were distributed to the selected consumers via the help of a group of trained 1st year pharmacy students after obtaining their verbal consent for participation. For a period of 5 days, 400 respondents consented and participated in the survey. Analysis of the response from the collected forms yielded in 396 usable forms.

Both non-parametric statistical tests and appropriate descriptive statistics for demographic characteristics (mean and standard deviation for age; distribution for gender and method of entry to medical school) were performed using SPSS for Windows, v.12. Responses to questions producing ordinal data were compared to detect differences according to demographic characteristics using Fisher's exact test. Fisher's exact test was used because it is considered to be more appropriate for skewed data, as were obtained in this survey. Furthermore, as a rule of thumb, if $25 \%$ or more of the cells in the table have expected frequencies less than 5 , or if any expected frequency is less than 1, then Fisher's exact test is preferred over the Chi-squared test. For this survey data, a default Monte Carlo simulation in the SPSS software was used to estimate Fisher's exact p-values as the data set was large and normal exact computations require a great amount of computer time and memory. A twosided $99 \%$ confidence level Monte Carlo estimate of Fisher's exact $p$-value was computed, with a pvalue of 0.05 or less taken to demonstrate statistical significance.

\section{RESULTS}

$143(36.1 \%)$ of the respondents were male. Ethnicity wise, $210(53.0 \%)$ of the total respondents were Malay, 136 (34.3\%) of them were Chinese, and $38(9.6 \%)$ were Indian. $12(3.0 \%)$ respondents belongs to other ethnicity group. The age distributions, academic qualification and income of 
respondents are shown in Tables 1, 2 and 3 respectively.

\begin{tabular}{|c|c|c|}
\hline \multicolumn{3}{|c|}{ Table 1: Respondents' age groups } \\
\hline Age group & Frequency & Percent \\
\hline$<20$ years old & 117 & 29.5 \\
\hline $21-30$ years old & 147 & 37.1 \\
\hline $31-40$ years old & 70 & 17.7 \\
\hline $41-50$ years old & 34 & 8.6 \\
\hline$>50$ years old & 28 & 7.1 \\
\hline Total & 396 & 100.0 \\
\hline
\end{tabular}

\begin{tabular}{|c|c|c|}
\hline \multicolumn{3}{|c|}{ Table 2: Respondents' highest qualification } \\
\hline Qualification & Frequency & Percent \\
\hline Primary School & 10 & 2.5 \\
\hline High school & 125 & 31.6 \\
\hline Pre-University & 102 & 25.8 \\
\hline Certificate/Diploma & 50 & 12.6 \\
\hline Undergraduate & 97 & 24.5 \\
\hline Postgraduate (MSc, PhD) & 3 & 0.8 \\
\hline Others/none & 9 & 2.3 \\
\hline Total & 396 & 100.0 \\
\hline
\end{tabular}

Table 3: Respondents' monthly income

\begin{tabular}{|c|c|c|}
\hline Personal Income & Frequency & Percent \\
\hline $\begin{array}{c}\text { < MYR 1000 } \\
(<\text { USD294) }\end{array}$ & 247 & 62.4 \\
\hline $\begin{array}{c}\text { MYSD 2001- MYR 3000 } \\
\text { (USD588 - USD882) }\end{array}$ & 43 & 17.2 \\
\hline $\begin{array}{c}\text { MYR 3001- MYR 4000 } \\
\text { (USD882 - USD1176) }\end{array}$ & 22 & 5.6 \\
\hline $\begin{array}{c}\text { MYR 4001- MYR 5000 } \\
\text { (USD1176 - USD1470) }\end{array}$ & 9 & 2.3 \\
\hline $\begin{array}{c}\text { MYR 5001- MYR 6000 } \\
\text { (USD1470 - USD1764) }\end{array}$ & 3 & .8 \\
\hline $\begin{array}{c}\text { >MYR 7000 (USD2058) } \\
\text { Total }\end{array}$ & 4 & 1.0 \\
\hline \multicolumn{2}{|c|}{396} & 100.0 \\
\hline Conversion rate: MYR 1 = USD 0.294
\end{tabular}

From the data collected, $28.3 \%$ or 112 respondents are familiar with the term 'Generic Medicines'. Meanwhile $71.7 \%$ or 284 people are unfamiliar with the term. This shows that more than $70 \%$ of respondents are not well informed about generic medicines. There was a significant association between this question and respondents' qualifications (Fisher Exact $=15.631, \mathrm{p}=0.022$ ). When asked if they know that generic medicines can be marketed under different brand names, 180 respondents (45.5\%) answered by "Do not know", 111 respondents $(28 \%)$ answered by "Yes", while 105 respondents $(26.5 \%)$ answered by "No". When testing for association between this question and demographic variables, there was a significant association between respondents' qualification and personal income (Fisher's Exact $=25.165, p=0.021$, and 20.862, $p=0.027$, respectively).

From the 112 respondents who said they were familiar with the term "Generic Medicines", 38 respondents $(33.9 \%)$ learned that from their pharmacists, 29 respondents (25.9\%) from their physicians, 26 respondents $(23.2 \%)$ from reading materials like newspapers, 15 respondents (13.4\%) from mass media like TV and Radio. In their answers for the question "Do you think that the public should be educated about generic medicines", 319 respondents (80.6\%) answered with "Yes", while 18 (4.5\%) answered with "No", and 54 (14.9\%) with "Don't know".

When asked how they compare between generic medicines and branded ones in terms of quality, effectiveness, side effects and cost, $8.6 \%$ or 34 respondents stated that the quality of generics is higher than the branded counterparts, $52.5 \%$ or 208 respondents agreed that the quality of both is equal, while $38.9 \%$ or 154 respondents stated the quality of generics as less than branded medicines. When testing for association between this question and respondents' demographics, only age group was found to have a statistically significant relationship (chi square $=6.036, d f=8, p=0.042$ ). Ten percent of respondents (41 respondents) stated that the effectiveness of generics is higher than branded medicines. $54.8 \%$ (217 respondents) stated that both are equal in effectiveness, $34.8 \%$ (138 respondents) agreed that generics are less effective than branded one. When testing for association between this question and respondents' demographics, only age group was found to have a statistically significant relationship (chi square $=17.52, \mathrm{df}=8, \mathrm{p}=0.022$ ).

In term of side effects, 127 respondents (31.2\%) felt that generic medicines may cause more side effects, 194 respondents (49\%) said generics will result in the same side effects like branded ones, and 75 respondents (18.9\%) felt that generics will result in fewer side effects. When testing for association between this question and respondents' demographics, we found a statistically significant relationship between it and age group (chi square=27.154, $d f=8, \quad p=0.001$ ), with the relationship between the two being negative, meaning as age increase the less perceived side effects due to generic medicines. There was also an association between perceived side effects and ethnic group (chi square $=5.974, d f=6, p=0.014$ ), with highest qualifications (Fisher's exact $=23.583$, $\mathrm{p}=0.031$ ), and with personal income (Fisher's exact $=25.655, p=0.005$ ).

In this study most of the respondents (63.4\%) answered correctly that generics cost less than branded medicines. When testing for association between this question and respondents' demographics, only respondents' qualification has a statistically significant relation (Fisher's Exact $=27.561, p=0.009$ ). The relationship between the two variables is negative i.e. as the education level increase, the perception of having generic medicines with high cost decrease.

In a question about respondents' out of pocket expenses per month, it was found that majority of respondents (88.4\%) spend less than MYR 50.00 (USD14.70) per month on medicines. There was a significant association between age group and out of pocket expenses (Fisher's Exact $=41.789$, $p<0.001)$. The relationship between the two variables is positive i.e. as the age increase, out of pocket expenses increase. Another significant association is between out of pocket expenses and qualification (Fisher's Exact $=37.511, \mathrm{p}<0.001$ ), with this relation being negative i.e. as the qualification 
increase the out of pocket expenses decrease. Also a significant association exists between personal income and out of pocket expenses (Fisher's test $=39.799, \mathrm{p}<0.001)$.

In this study we tried to explore to what extent consumers trust their healthcare providers in the provision on information pertaining to the drugs. Using three sequential questions, we found that more than $75 \%$ of the respondents would be more likely to purchase a generic medicine if their pharmacists, or physicians, respectively advised it is all right. These results was also supported by the answer to the third question which showed that 180 respondents $(45.5 \%)$ will not change a medicine prescribed by their physician or suggested by their pharmacist from generic to branded one. The answers for the first, second questions did not show any association with demographics of the respondents. The third question showed an association with age group (chi square $=16.166$, $d f=8, \quad p=0.040)$ and with qualification of the respondents (Fisher's Exact $=29.157, \quad d f=14$, $\mathrm{p}=0.005$ )

In order to explore self usage of generic medicines, we used three sequential questions. In their answers for the first question which asked them if they have ever purchased a generic medicine, 174 respondents (43.9\%) answered by "Yes", 118 $(29.8 \%)$ answered by "No", 104 (26.3\%) answered by "Don't know'. These results differed in the second question answers, which showed that more than $74 \%$ of the respondents never or rarely purchased a generic medicine. The second question suffered from bad wording in term of choosing the response word (randomly) which affected the way that respondents answered it and make its results invalid. In their answer for the third question which asked them for what medical condition they are using generic medicines, majority of them $(78.3 \%)$ said they use generics for simple ailments like headache, flu and fever, while only $(1.5 \%)$ will use for serious conditions like diabetes.

\section{DISCUSSION}

Medications represent a special kind of goods whereby there are usually three players consisting of consumers, pharmacists, and physicians. Price or cost of generic medicines is obviously important; since cost is the reason generic medications are considered in the first place. ${ }^{14}$ However, consumers do not judge directly the suitability of their medicines. The physician acts as a purchasing agent for the patient in choosing the most appropriate medication. ${ }^{15}$ In this survey, we tried to explore consumers' knowledge and understandings about generic medicines. The findings from this pilot study had shown that consumers in Malaysia are relatively less knowledgeable towards issues surrounding generic medicines compared to their counterparts in developed countries. ${ }^{13}$ Many factors may lead to low familiarity with generic drug; one of them is the lack of communication between healthcare professionals and patients-consumers.
The answers to the second question shows that our respondents are not aware of the process of naming medicines, patenting, and the differences between the generic and trade name of a drug. This explanation is supported by the finding from the first question. The significant associations with highest qualifications and personal income are expected as people who are more educated are more knowledgeable about these issues, and this may also be explained by the increase of personal wealth which will lead to more spending on reading and health seeking behavior thus exposing the person more to issues surrounding medicines' commercializing.

This study shows that consumer's main sources of information about their medicines come from pharmacists and physicians to them. However, it also shows the inadequate use of mass media and reading sources to educate people. Therefore, it is important for the government, health organizations, and healthcare providers to pay more attention to use these sources more efficiently if generic medicine utilization needs to be increased from the current state in future.

With regards to lower confidence among consumers on the issues surrounding quality, effectiveness, safety, and side effects of a generic drug, respective stakeholders in the quality use of medicines framework need to convince the consumers that both generic and brand name medicines need to fulfill the same safety and effectiveness criteria before it can be marketed. However, there are still opposite responses and endless doubts. Firstly, this may be originated from their previous generic drug usage experiences. Secondly, this attitude may arise because of their mindset which insists that branded medicines are always better. Thirdly, another factor that may lead to this scenario is the lack of advice from health professionals. Last but not least, there is a psychological complex which make both respondents and health professionals believe that medicine made in western countries are always better than medicines made locally or regionally. All these factors do contribute and greatly affect the patients' presumption and acceptance.

The current study also found that consumers were more likely to use generic medicines in order to treat simple ailments like headache, flu and fever compared to more chronic and complex diseases. This finding is consistent with the findings from other study which suggested that consumers always do not take risk by changing their existing medication for their treatment due to their belief that any changes in brands can worsen their existing condition. $^{13}$ The current findings also had highlighted that healthcare professionals in Malaysia can play more active role in educating consumers' about quality use of generic medicines, especially with the high level of trust that respondents showed in their healthcare providers.

The present study also has some of it own limitations. The first limitation is small sample size of respondents were used in order to elicit their responses towards issues pertaining to generics. 
This small sample size might affect the generalisability of this study to the larger population of Malaysia. Besides that, the use of non-probability sampling technique may cause some response bias to occur among participants. It was suggested a larger population based study need to be conducted in order to generalize the current study finding to larger population.

\section{CONCLUSIONS}

The present study showed that there is a gap in consumers' knowledge and understanding of generic medicines. Regarding respondents' information about generic medicines, the survey showed two results; firstly, healthcare providers (pharmacists and physicians) are considered to be the most used sources by our respondent and that is consistent with their profession. Secondly, it highlighted there is lack of utilization of appropriate resources such as mass media in educating consumers about their medications.

Although there are some limitations with the methods used, the current findings from this first ever pilot study conducted in this country can be used by the interested stakeholders especially the government and generic medicines proponents to devise a national strategy in educating consumers on the role of generics.

\section{ACKNOWLEDGEMENTS}

The authors would like to thank Mr. Ong Xi Zhou and his group members for helping in distribution of the survey forms to the respondents.

\section{CONFLICT OF INTEREST}

None declared.

\section{References}

1. World Health Organization. Multisource (Generic) Pharmaceutical Products: Guidelines on Registration Requirements to establish Interchangeability. Working Document QAS/04.093/Rev. 4; 2005.

2. Kanavos P. Financing pharmaceuticals in transition economies. Croat Med J 1999;40:244-259

3. Karim S, Pillai G, Ziqubu-Page TT, Cassimjee MH, Morar MS. Potential savings from generic prescribing and generic substitution in South Africa. Health Policy Plan 1996;11: 198-205.

4. Ping CC, Bahari MB, Hassali MA. A pilot study on generic medicine substitution practices among community pharmacists in the State of Penang, Malaysia. Pharmacoepidemiol Drug Saf 2008; 17(1):82-89 DOI: 10.1002/pds.1477

5. National Pharmaceutical Control Bureau. About Drug Control Authority. 2007; Available from: http://www.bpfk.gov.my/ [Accessed 3/10/2007];

6. Abdul Latiff SB. Regulations and policies on pharmaceuticals in Malaysia: its impact on healthcare. The Kaohsiung Journal of Medical Sciences. 1999; 15(Suppl): s75-s78.

7. Organization WT. Trade Policy Review : Malaysia. 1997 Available from: http://www.wto.org/english/tratop_e/tpr_e/tp67_e.htm [cited 2007 5th October];

8 Azmi IM, Alavi R. Trips, Patents, Technology Transfer, Foreign Direct Investment and the Pharmaceutical Industry in Malaysia. Journal of World Intellectual Property. 2001;4(6):947-76.

9. Razak DA. Going Generic and Bringing Health To All. The New Straits Times Online 1998.

10. Joncheere Kd, Rietveld AH, Huttin C. Experiences with generics. In: Dukes MNG, Haaijer-Ruskamp FM, and CPdJ, Rietveld AH, eds. Drugs and Money. 7 ed. Amsterdam: IOS Press 2002:101-10.

11. Hassali MA, Kong D, Stewart K. Generic medicines: perceptions of consumers in Melbourne, Australia. Int J Pharm Pract. 2005; 13(4):257-64.

12. Tootelian DH, Gaedeke RM, Schlacter J. Branded versus generic prescription drugs: perceptions of risk, efficacy, safety, and value. Journal of health care marketing.1988 Sep;8(3):26-9.

13. Ganther JM, Kreling DH. Consumer perceptions of risk and required cost savings for generic prescription drugs. J Am Pharm Assoc 2000; 40(3):378-83.

14. Sanborn MD, White SJ. Pharmacists' perceptions and practices regarding the purchase of multisource pharmaceuticals. Hospital Pharmacy 1993; 28(2):104-6, 9-13.

15. Burstall ML. The management of the cost and utilisation of pharmaceuticals in the United Kingdom. Health Policy 1997;41(Suppl):s27-s43 